\title{
CRY2 wt Allele
}

National Cancer Institute

\section{Source}

National Cancer Institute. CRY2 wt Allele. NCI Thesaurus. Code C106140.

Human CRY2 wild-type allele is located in the vicinity of 11 p11.2 and is approximately 36 $\mathrm{kb}$ in length. This allele, which encodes cryptochrome- 2 protein, plays a role in the regulation of circadian rhythms. 